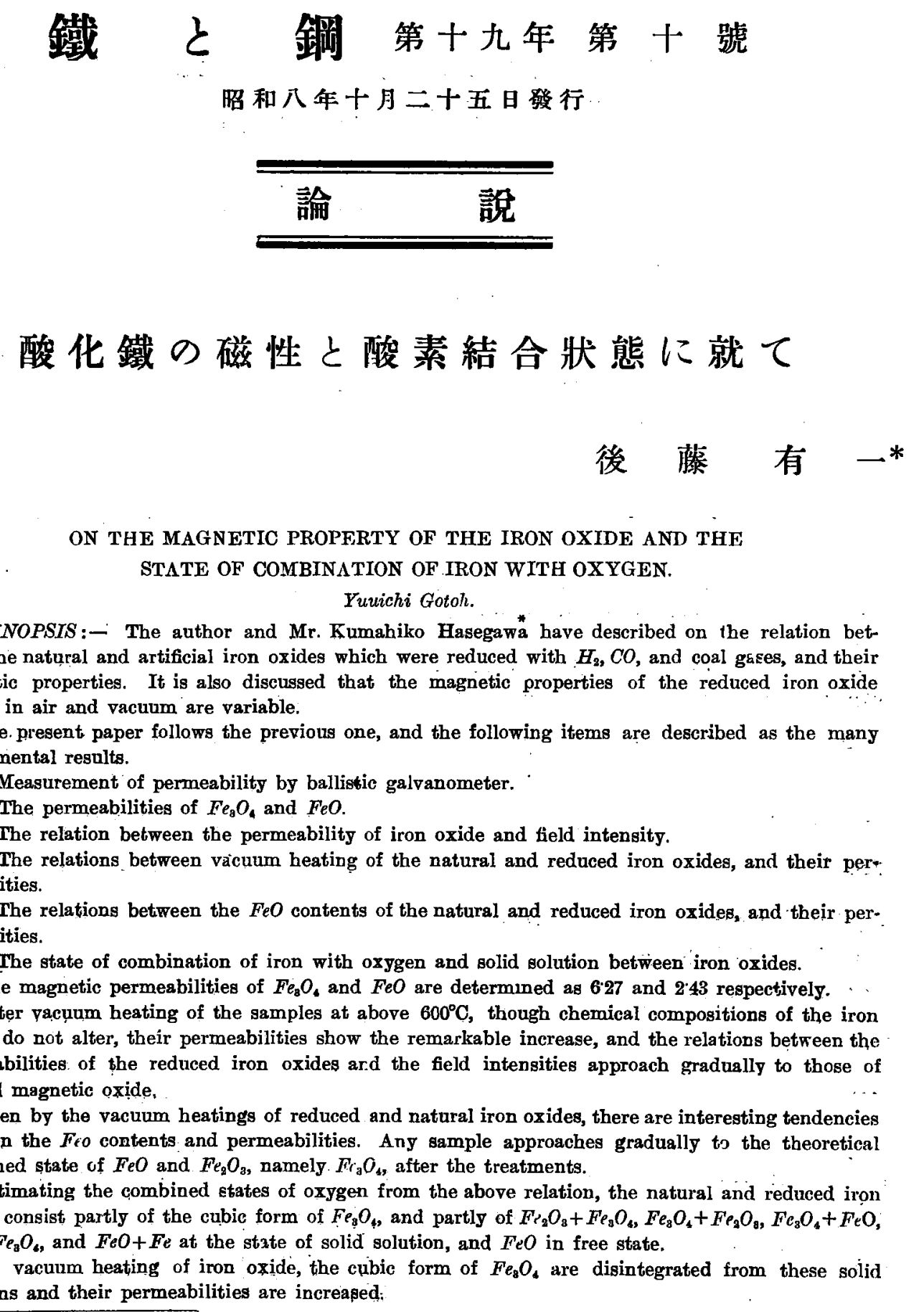

* K. Hasegawa and Y. Gotoh TFiTSU TO HAGANE, The Jounral of the Iron and Steel Institute of Japan. Vol. XIX, No. 8.
目
次
I. 緒
言

I 緒言。 II 薄磁率測定方法。 III 磁鐵鏣の 漯磁率， IV $\mathrm{FeO}$. の尊磁率， V 各種酸化鐵の. 薄磁柪上磁場上の關係，VI 天然磁鐵䤡及び 還元 試料寅空加熱。 VII 酸化鐵の合有 $\mathrm{FeO}$ 女導磁率 の關係，VIII 酸素結合狀態と固溶態。IX 總括

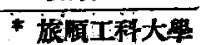

\begin{abstract}
䓔者は先に長谷川㦝彦比との共著“天然及び人工整酸化 鐵の酸化還元と磁性” ${ }^{1}$ ) に於て酸化鐵を $H_{2}$ 瓦斯、石炭瓦 斯 $C O$ 瓦斯にて還元して還元成生物之磁性の關係发び還元 試料と酸化及び冥空加熱した場合の磁性の變化に就きて述

门長谷川、後藤 践と銅 第十九年 第八號
\end{abstract}


ごた。本文は其の續編にしてC $O$ 瓦斯還元を緢行してFeO

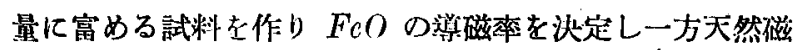

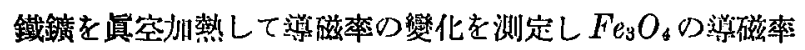

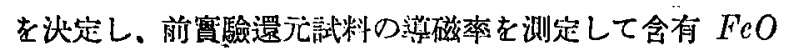

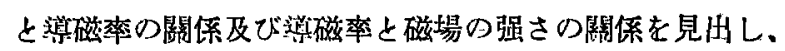

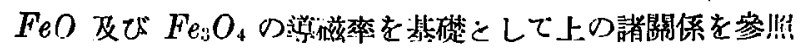
して還元にて得たる諸種酸化物及び天然磁鐵鑛の酸素結合 状態を推理せしるのである。

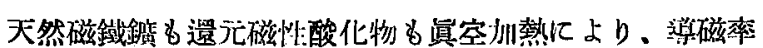

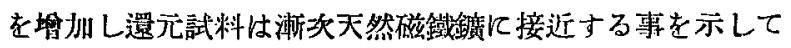
みる。

\section{II. 藮磞率測定方法}

雒動電流計を用とてコイルに試料を入れて時と空の時と の振れを測定すれば次の算式に上り導磁率 $\mu$ 老測定し得

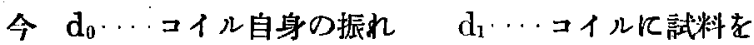
入れたる時の振れ $\mathrm{A}_{\mathbf{0}} \cdots$ コイルの平均断面皘 $A_{1} \cdots$ ・イルの內斷面锖 $\quad \mu \cdots$ 導磁卒 とすればコイル空の時の振れは其の中を通る磁束 $\mathrm{A}_{0} \mathrm{H} に$ 比例する故化 $\mathrm{d}_{0}=\mathrm{CA}_{0} \mathrm{H}$

試料を入れたる時の磁束は

$$
\left(A_{0}-A_{1}\right) H+A_{1} B=\left(A_{0}-A_{1}\right) H+A_{1} \mu H
$$

振准 $\mathrm{d}_{1}=\mathrm{c}\left[\left(\mathrm{A}_{0}-\mathrm{A}_{1}\right) \mathrm{H}+\mathrm{A}_{1} \mu \mathrm{H}\right]$

$$
\begin{gathered}
\frac{d_{1}}{d_{0}}=\frac{\left(A_{0}-A_{1}\right) H+A_{1} \mu \cdot H}{A_{0} H}=R \\
\mu=\frac{A_{0}}{A_{1}} R-\frac{A_{0}-A_{1}}{A_{1}}
\end{gathered}
$$

本筫駼に於ては

$$
\begin{aligned}
& A_{0}=\left(\frac{775}{2}\right)^{2} \times \pi=4717 m^{2} \\
& A_{1}=\left(\frac{540}{2}\right)^{2} \times \pi=22 \cdot 90 m i^{2}
\end{aligned}
$$

故江 $\mu=2.06 \mathrm{R}-1.06$

$$
l=10 \cdot 1 \mathrm{~cm} \text { ちれば 容積 } \mathrm{V}=2 \cdot 29 \times 10 \cdot 1=2 \cdot 313 c c
$$

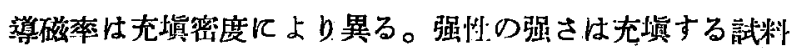
の重量に比例する故に测定せる尊磁率上り次式に上りある 一定の充媜密度の時の $\mu$ 老出，严事老得。?

今 $\mu_{\mathrm{c}} \cdots$ 光壃密度 $2.65 \mathrm{gr} / \mathrm{ec}$ の侍の導磁率 $\boldsymbol{\mu}_{2} \cdots \cdots$ 測定せる導磁率。

-2) A. Welo and Oskar Baudiseh Philosophical Magazine Vol. 50 No. $1,1925$.

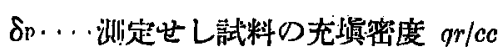

$$
\text { とすれば } \mu_{\mathrm{c}}=\left(\mu_{0}-1\right) \frac{265}{\delta_{\mathrm{p}}}+1 \ldots \ldots \ldots
$$

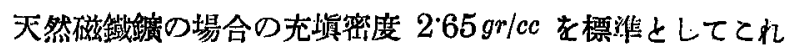
几換算して算出せり。

同樣にして P\% 酸化物試料上り 100\% の装命の導磁率 を次式にて計算する事を得。

$$
\begin{aligned}
& \mu_{0} \cdots \mathrm{P} \% \text { 酸化物の導磁率。 } \\
& \mu_{\mathrm{c}} \cdots 100 \% \text { の場合の導磁率。 } \\
& \mu_{\mathrm{c}}=\left(\mu_{0}-1\right) \frac{100}{\mathrm{P}}+1 \cdots \cdots
\end{aligned}
$$

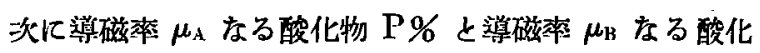

\begin{tabular}{|c|c|c|c|c|c|c|c|}
\hline \multirow{2}{*}{ 種 } & \multicolumn{3}{|c|}{$\begin{array}{r}\text { 第 } 1 \\
\text { 分析結果 }\end{array}$} & \multicolumn{3}{|c|}{ 組。合 } & \multirow{2}{*}{ 薄磁來 } \\
\hline & 全践 & $\mathrm{FeO}$ & $\mathrm{Fe}_{2} \mathrm{O}_{8}$ & $\mathrm{Fe}_{3} \mathrm{O}_{4}$ & 過剩 & $\begin{array}{l}\text { 渦剩 } \\
\mathrm{Fe}_{9} \mathrm{O}_{8}\end{array}$ & \\
\hline 鞍山精鑛 & $72 \cdot 26$ & $30^{\circ} 94$ & $68: 93$ & $99 \cdot 7 \mathrm{I}$ & 0 & $\begin{array}{r}0.16 \\
0.68\end{array}$ & $5 \cdot 30$ \\
\hline 本溪湖磁鐵銥 & $71 \cdot 85$ & $30 \cdot 84$ & $68 \cdot 46$ & $99 \cdot 26$ & 0.04 & 0 & $5 \cdot 83$ \\
\hline 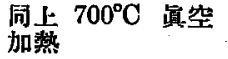 & $71 \cdot 89$ & $30 \cdot 89$ & $68 \cdot 46$ & $99 \cdot 26$ & 009 & 0 & 623 \\
\hline $\begin{array}{l}\text { 人工留 } \mathrm{Fe}_{2} \mathrm{O}_{3} \mathrm{CO} \\
\text { 丽斯 } \\
\text { 試料 }\end{array}$ & $71: 55$ & $26^{\prime} 53$ & $72 * 49$ & 85.58 & 0 & $13 \cdot 43$ & $4 \cdot 45$ \\
\hline 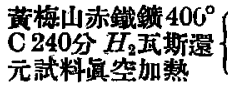 & $71 \cdot 79$ & 30.85 & 68.07 & $98 \cdot 68$ & 024 & 0 & 3.97 \\
\hline
\end{tabular}
物 $\mathrm{q} \%$ の混合物の障磁率を $\boldsymbol{\mu}$ とすれば

$$
\begin{aligned}
& \mu=\left(\mu_{\mathrm{A}}-1 ; \frac{\mathrm{P}}{100}+i \mu_{\mathrm{B}}-1\right) \frac{\mathrm{q}}{100}+1 \\
& \text { 磁場の强さは } \quad \mathrm{H}=\frac{4 \pi \times 1742}{10 \times 40} \times \ddot{i} \\
& i=5 \mathrm{amq} \text { なれば } \mathrm{H}=274 \text { ガウス である。 }
\end{aligned}
$$

文中記载の分析㹥全鐵及び二價の鐵は夫ょ室氣中 $\mathrm{CO}_{2}$ 瓦断中にて $6 \mathrm{~N}-\mathrm{HCl}$ にて溶解して $\mathrm{KMnO}_{4}$ にて摘定し て得た綃果でして、金風鐵は $\mathrm{CO}_{2}$ 瓦斯中にて $\mathrm{FeCl}_{3}$ 亿溶

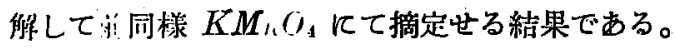

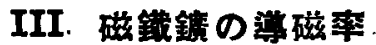

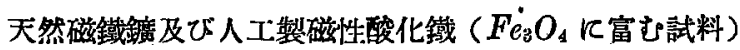
の梁磁率を前述の方法にて測定して次の結果を得た。

上述せる如く分析組合せ亿依る $\mathrm{Fe}_{\mathrm{e}} \mathrm{O}_{4}$ 量と渻磁率とは 比例せ才、本溪湖磁鐵鑛は分析上 $\mathrm{F}_{\mathrm{H}} \mathrm{O}_{4} \mathrm{O}_{4}$ 量以鞍山精鑛と

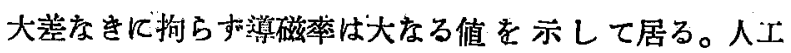
$\mathrm{Fe}_{2} \mathrm{O}_{3} 250^{\circ} \mathrm{C} \mathrm{CO}$ 瓦斯還元試料㶎元溫度低< $\mathrm{Fe}_{3} \mathrm{O}_{4} \rightarrow$ $\mathrm{FeO}$ の變化進み蜼く，分析上の $\mathrm{Fe}_{3} \mathrm{O}_{4}$ は大部分 $\mathrm{Fe}_{3} \mathrm{O}_{4}$ の形にて存在L。少量の不安定低級酸化物存在する8のK

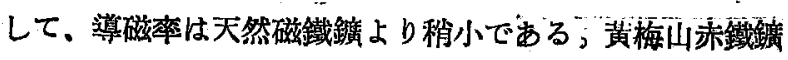


$400^{\circ} \mathrm{C} 240$ 分 $H_{2}$ 瓦斯還元陚料恃 $F_{3} O_{4} \leftarrow$ 上り、更に 還元進み分析上 $\mathrm{Fe}_{\mathrm{g}} \mathrm{O}_{4}$ なる 子實際は一部分不安定なる低 級酸化物及び承々の固溶體として存在して居るるのと推理 され導磁卒は著しく小なる値を示して居る。てれは分析組 合壮 $\mathrm{FeO}$ 及び $\mathrm{Fe}_{2} \mathrm{O}_{3}$ 孝組合せ $\mathrm{Fe}_{3} \mathrm{O}_{4}$ として算入して居

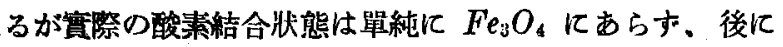
推理する如く程くの形にて存在して居る䉆めでする。即ち 酸素の結合狀態江伤り著しく磁性に差異あるるのである。 後逝する如くてれら分析組合せの $\mathrm{F}_{33} \mathrm{O}_{4} \%$ に比して磁性

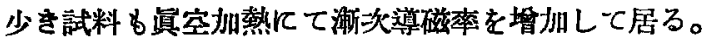

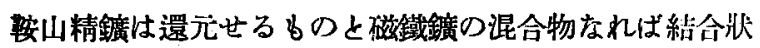

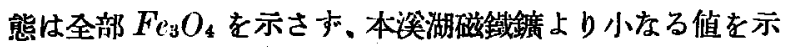

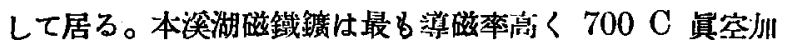
熱せるものは 6.23 示し $1,000^{\circ} \mathrm{C}$ 亿真空加熱するる殆 んど變化を示さない，ての導磁率值は實驗的に得られる最

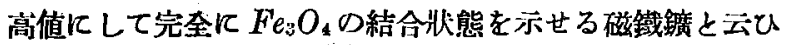
得るが故に $100 \% \mathrm{Fe}_{3} \mathrm{O}_{4}$ の場命の蕉磁率を求むればけ2 27

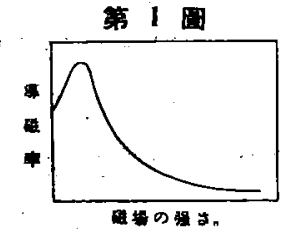

2 㲾 2

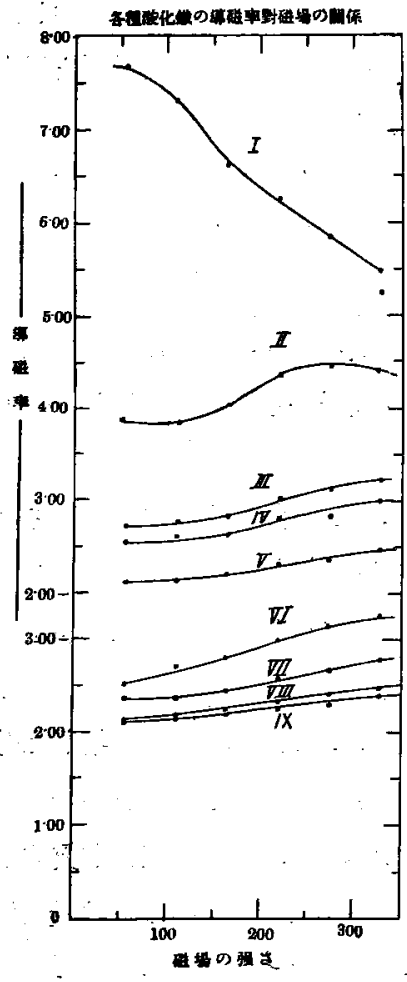

になる。即ち磁鐵摭の装

磁率は 627 である。

\section{IV. $\mathrm{FeO}$ の導磁率}

$\mathrm{FeO}$ は酸化され易く 單體として得る事は困難 である。天然赤鐵鑛を $C O$ 瓦斯を通して還元す る時は $\mathrm{Fe}_{2} \mathrm{O}_{3} \rightarrow \mathrm{Fe}_{3} \mathrm{O}_{4} \rightarrow$ $\mathrm{FeO}$ の變化進行して大 部分 $\mathrm{FeO}$ 亿變吉る。期 与 $350^{\circ} \mathrm{C} 300$ 分 $\mathrm{OO}$ 瓦 斯還元試料怯 $\mathrm{FeO} 89^{\circ}$ 18\%含有し導磁率は 227 であ。この場合は 金屬鐵 $438 \%$ 文少量の 岁素を含有して居るが。 $\mathrm{Fe}$ は $\mathrm{FeO}$ 亿固溶す る.ものと推理し得へく。 脽磁率蛙 $\mathrm{HeO}$ 几依る るのと教へられる。印ち CO 瓦斯還元試料の管磁 率2227 老含俏 $\mathrm{FeO}$ 几位

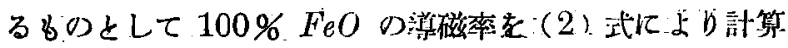
すれば 243 となる。印古 FeO D尊磁率を 243 とする。

\section{V. 各種酸化鐵の導磁率對磁場の關係}

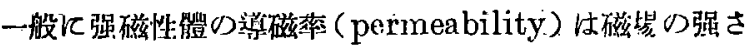

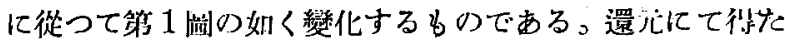

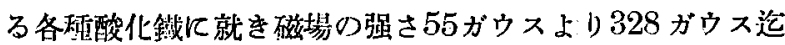
戀化して懯磁率を测定すれば第 2 装及び第 2 圖の如く店る

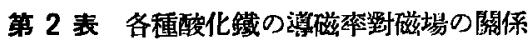

\begin{tabular}{|c|c|c|c|c|c|c|}
\hline 磁場の强さ & \multicolumn{6}{|c|}{ 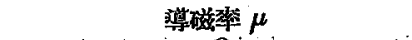 } \\
\hline 别 & 55 & 109 & 164 & 219 & 274 & 328 \\
\hline 鐵銭。 & $7 \cdot 68$ & $7 \cdot 31$ & $6 \cdot 61$ & 624 & $5 \cdot 83$ & $5 \cdot 47$ \\
\hline $\begin{array}{l}\text { 人工 } F e . O_{3} 250^{\circ} \mathrm{C}, 90 \text { 分 } \\
C O \text { 正斯遥元試料。 }\end{array}$ & $3 \cdot 86$ & $3 \cdot 82$ & 402 & $4: 36$ & 4.45 & 140 \\
\hline 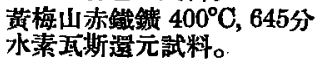 & $2 \cdot 70$ & $2 \cdot 75$ & $2 \cdot 79$ & 3.00 & $3 \cdot 10$ & $3 \cdot 20$ \\
\hline 闹声 $400^{\circ} \mathrm{O}, 250$ 分 & $2: 52$ & $2 \cdot 59$ & $2 \cdot 60$ & 278 & $2 \cdot 81$ & 297 \\
\hline 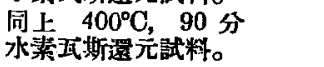 & 209 & $2 \cdot 11$ & 218 & 230 & $2 \cdot 36$ & $2 \cdot 46$ \\
\hline 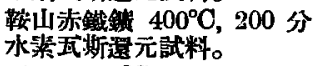 & 250 & 269 & 277 & 297 & $3 \cdot 12$ & $\mathbf{3} \cdot 24$ \\
\hline $\begin{array}{l}\text { 同上 } 400^{\circ} \mathrm{C}, 100 \text { 分 } \\
\text { 水素互斯還元試料。 }\end{array}$ & $2 \cdot 36$ & $2 \cdot 36$ & $2 \cdot 43$ & $2: 56$ & 265 & 277 \\
\hline $\begin{array}{l}\text { 同上 } 350^{\circ} \mathrm{C}, 300 \text { 分 } \\
C O \text { 五斯遺元試料。 }\end{array}$ & $2 \cdot 10$ & $2 \cdot 17$ & $2 \cdot 18$ & $2 \cdot 22$ & $2 \cdot 27$ & $2 \cdot 37$ \\
\hline $\begin{array}{l}\text { 上 } 400^{\circ} \mathrm{C}, 250 \text { 分 } \\
\text { O瓦撕逪元試料。 }\end{array}$ & 212 & $2: 16$ & $2 \cdot 20$ & 231 & 238 & 77 \\
\hline
\end{tabular}

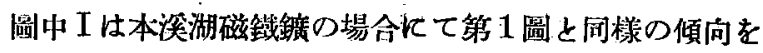
有し磁場の强さ50ガウス附近にて䆃磁率最大俻を示し100 ガウス附近上り急に減少し以後殆んぎ遖線的に減少を示し て居る。曲線 II は人工製 $\mathrm{Fe}_{2} \mathrm{O}_{3} \cdot 250^{\prime} \mathrm{C} 90$ 分 $\mathrm{CO}$ 瓦斯

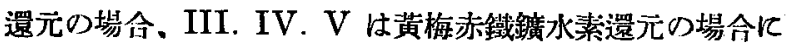
て夫夕 III は $400 \mathrm{C} 645$ 分. IV は $400^{\circ} \mathrm{C} 250$ 分、V は $400 \mathrm{C} 90$ 分還元の場合である。VI. VII は鞍山赫鐵 鋠水素瓦斯還元せるものにて夫心 $400^{\circ} \mathrm{C} 200$ 分、 $400^{\circ} \mathrm{C}$ 100 分還元の場合である。

還元試料は何れの場合も天然磁散鑛とは異なる傾向を示

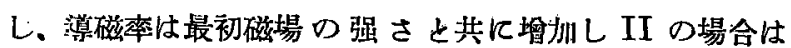
270 ガウス. III. IV. VV の水素還元の場合は 330 ガウス 附近にて最大噂磁率を示して居る。毁ち最大導磁來を示す 點が渐次 50 ガウスより 270 ガウス. 330 ガウスに移動 达るものと考へられる。てれは後述する妨く還元試料蛙完

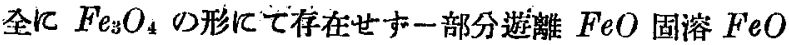
及び $\mathrm{Fe}_{2} \mathrm{O}_{3}$ として存在する第である。而して人工 $\mathrm{F}_{2} \mathrm{O}_{3}$ $\mathrm{CO}$ 瓦斯還元の場合は殆ん $\mathrm{E} \cdot \mathrm{Fe}_{3} \mathrm{O}_{4}$ の形飞て一部 $\mathrm{FeO}$,

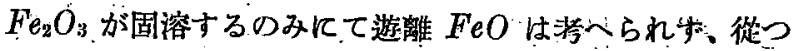
て天然磁鉝鉷と水素還元せし場合の中間の傾向を示して居 
る。VIII. IX は夫火 $400^{\circ} \mathrm{C} 250$ 分. $350^{\circ} \mathrm{C} 300$ 分 $\mathrm{CO}$ 瓦斯還元せし場合にて最初 150 ガウス迄は導磁率の坦州は 粰漫であるが 160 ガウス上り参になり 350 ガウス附近に

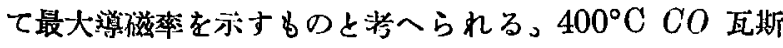

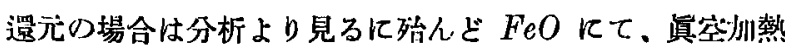
せる場合当 $\mathrm{Fe}_{3} \mathrm{O}_{4}$ の場命と異り $600^{\circ} \mathrm{C}$ Kて磁篓變態を 小さホ $\mathrm{FeO}$ と見做し得べき試料である。故に FeO の㭶 合の導磁率對磁場の關係はVIIIの如く變化する为のと考 一られる。

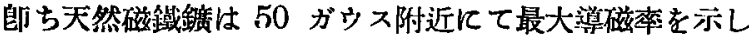
以後磁場の增加に從ひ減少して居るが $F e O$ は磁場め增州 に從ひ導磁率を徐々に增加し 350 ガウス附近にて最大值 を示して居る， $\mathrm{H}_{2}$ 瓦斯還元試料及び人工 $\mathrm{Fe}_{2} \mathrm{O}_{3} \mathrm{CO}$ 互将 還元試料は兩者の中間にて 270,330 ガウス附近にて最大 導磁率を示して居る。

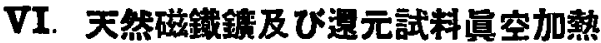

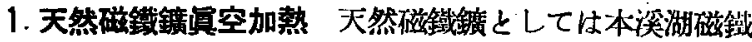

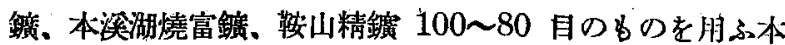
身 3 天然磁鐵船直空加熱 後の導磁率粨磁埸の 閣倸

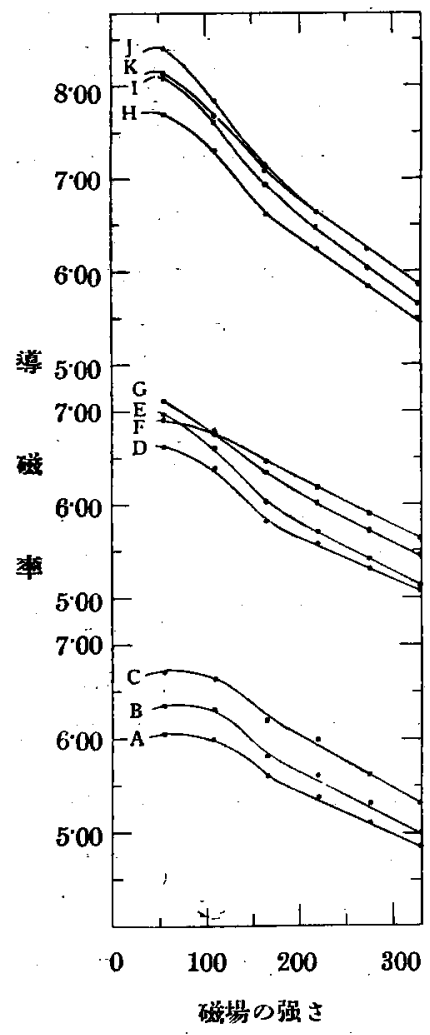

鹌 3 表

種 别 全 $\mathrm{FeO} \mathrm{Fe}_{2} \mathrm{O}_{3} \mathrm{Fe}_{3} \mathrm{O}_{4}$ 本溪湖 $71.850 .09 \quad 0 \quad 9920$ 本湖 $71.92 \quad 0 \quad 1 \cdot 14 \quad 93.29$ 燒富鐄 7192 精 $72 \cdot 26 \quad 0 \quad 0.16 \quad 9971$ $650^{\circ} \mathrm{C}, 800^{\circ} \mathrm{C}, 1,000^{\circ} \mathrm{C}$ Kて 1 時間其空州熱し噵 磁率對磁場の强さの關係 を求むれば第 3 圖及び第 4 表の如を絈果を得る。

圖中 $\mathrm{A}, \mathrm{B}, \mathrm{C}$ は本溪湖 燒富鏣の場合飞て $\mathrm{B}, \mathrm{C}$ は 夫年 $650^{\circ} \mathrm{C}, 1,000^{\circ} \mathrm{C}$ r て真空加熱世し場合 D,E， $\mathrm{F}, \mathrm{G}$ は鞍山精艔の場命K

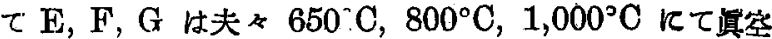

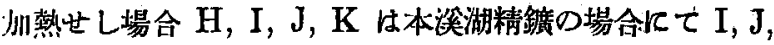
$\mathrm{K}$ は夫љ $650^{\circ} \mathrm{C}, 700^{\circ} \mathrm{C}, 1,000^{\circ} \mathrm{C}$ 真空州熱せ乚場合

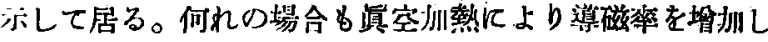
て、最大筧磁率を示す點が多少左に移動して居る。且し何

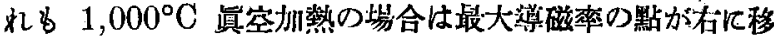
敌して居る。乙狆は $1,000 \mathrm{C}$ 杊熱にて多少 $\mathrm{Fe}_{2} \mathrm{O}_{3}$ 为分解 する䉆上洘へら机る。

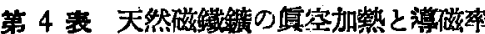

\begin{tabular}{|c|c|c|c|c|c|c|c|}
\hline & 磁場の强さ & & & & $\mu$ & & \\
\hline 别 & & $\overline{55}$ & 109 & 164 & 219 & 274 & \\
\hline 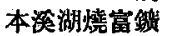 & & 6.03 & 5.98 & $5 \cdot 59$ & $5 \cdot 38$ & $5 \cdot 11$ & 4 \\
\hline $50^{\circ} \mathrm{C}$ & 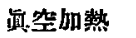 & 634 & 6.30 & $5 \cdot 79$ & $5 \cdot 60$ & $5 \cdot 31$ & \\
\hline $1,66^{\circ} \mathrm{C}$ & 䆬空加智 & $670^{\circ}$ & 6.62 & 6.19 & 5.97 & $5 \cdot 61$ & 5 \\
\hline 山精銈 & & $6 \cdot 60$ & 6.38 & $5 \cdot 81$ & 5.59 & $5: 30$ & \\
\hline 上 $650^{\circ} \mathrm{C}$ & 直空 & 695 & 6.61 & 6.02 & $5^{\prime} 69$ & $5 \cdot 41$ & \\
\hline 上 $800^{\circ} \mathrm{C}$ & 䆝空加热 & $7 \cdot 10$ & $6: 75$ & 6.35 & 6.02 & 5771 & \\
\hline $\mathrm{I}: \mathrm{J}, \mathrm{CO} 0^{\circ} \mathrm{C}$ & 椇空力 & 6.91 & 678 & 646 & 6.18 & 5.88 & \\
\hline 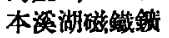 & & $7 \cdot 68$ & $7 \cdot 31$ & 661 & 624 & 583 & \\
\hline $650^{\circ} \mathrm{C}$ & & 8.08 & $7 \cdot 60$ & 6.93 & 647 & 602 & \\
\hline $700^{\circ} \mathrm{C}$ & 䆓空 & 840 & $7 \cdot 84$ & $7 \cdot 12$ & $6^{\circ} 64$ & 623 & \\
\hline $1,000^{\circ} \mathrm{C}$ & . & $8 \cdot 12$ & 766 & $7^{\circ} 09$ & 6.62 & $6 \cdot 20$ & \\
\hline
\end{tabular}

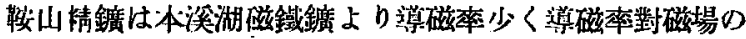

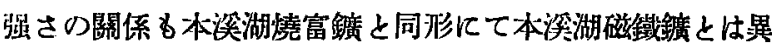

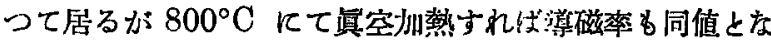

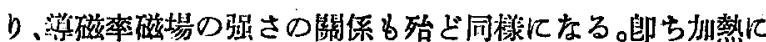
より本溪湖磁鐵鐄に近づくを見る。鞍山精鑛は還元鑛と天 然磁鐵銀の混合物にして後逝の如く種々の固溶體存在し。

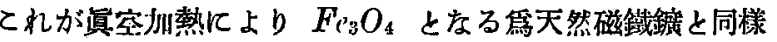
の導磁秉を示すに至るのである。

一般に天然磁鐵鑛は完全に $\mathrm{Fe}_{3} \mathrm{O}_{1}$ をなさす後迅する如

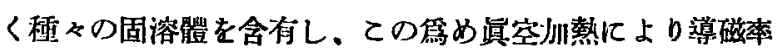
の增加を示して居る。

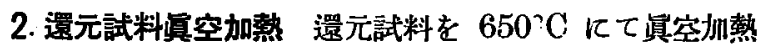
すれ代第 5 表に示す如く何れて場合す導磁率の坦加を示し て居る。

$\mathrm{H}_{2}$ 瓦斯還元試料悬空贺熱せる場合は分析結果を見るに

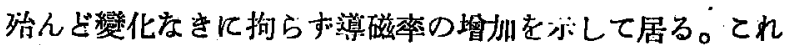
恃後述する如く酸素結合狀態變化して $F_{e} \mathrm{O}_{4}$ 立方體を成 生する篇である。

$C O$ 瓦斯還元試料真空加熱山る場合の導磁率の增加は分 析上り明かなる如く金屈鐵の分離によるものである。

鞍山赤鐵鑛 $350^{\circ} \mathrm{C} 250$ 分 $C O$ 瓦斯還元試料を真空加 熱しつ」導磁率を測定すれば第 4 圖の如く導磁率は最初還 元冷却曲線 I に沿ふて增し $230^{\circ} \mathrm{C} \sim 270^{\circ} \mathrm{C}$ 亿て念に減少 


\section{5 表 還元試料兵空加熱と導磁等}

\begin{tabular}{|c|c|c|c|c|c|c|c|c|}
\hline \multirow{3}{*}{ 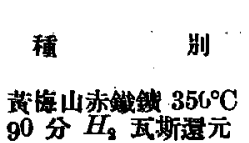 } & \multicolumn{4}{|c|}{ 分析粘果 } & \multicolumn{3}{|c|}{ 組合結染 } & \multirow{2}{*}{ 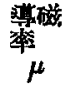 } \\
\hline & 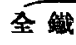 & 金网斜 & $\mathrm{Fe}_{\mathrm{g}} \mathrm{O}_{\mathrm{B}}$ & $\mathrm{FeO}$ & $\widetilde{\mathrm{Fe}_{2} \mathrm{O}_{4}}$ & $\mathrm{Fe}_{\mathrm{2}} \mathrm{O}_{\mathrm{a}}$ & $\mathrm{FeO}$ & \\
\hline & $69 \cdot 75$ & 0.47 & $81: 32$ & $13 \cdot 26$ & $42 \cdot 75$ & $54: 83$ & 0 & $1 \cdot 7$ \\
\hline 同上 $656^{\circ} \mathrm{C}$ 兴空加热 & $70 \cdot 83$ & 0.38 & $85 \cdot 23$ & 13.94 & 44.94 & $54: 23$ & 0 & $2 \cdot 08$ \\
\hline 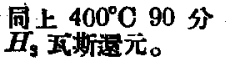 & $71 \cdot 93$ & 0.15 & $72 \cdot 85$ & $26 \cdot 10$ & 85.08 & $14: 17$ & 0 & $2 \cdot 49$ \\
\hline 同上 $650^{\circ} \mathrm{C}$ 资空加熹 & $71 \cdot 90$ & 0.27 & $78 \cdot 79$ & 2666 & 8591 & 1354 & $\mathbf{0}$ & 355 \\
\hline 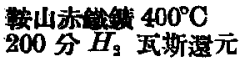 & $71 \cdot 68$ & 223 & $56 \cdot 10$ & $38: 87$ & $81: 34$ & 0 & $13 \cdot 62$ & $3 \cdot 12$ \\
\hline 同上 $650^{\circ} \mathrm{C}$ 空加缽 & $71 * 69$ & 0.82 & $60 \cdot 69$ & $36 \cdot 56$ & $87 \cdot 99$ & 0 & $9 \cdot 26$ & $\mathbf{3} \cdot \mathbf{8 1}$ \\
\hline 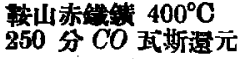 & $73 \cdot 02$ & $2 \cdot 10$ & $2 \cdot 60$ & $91 \cdot 60$ & $3 \cdot 77$ & 0 & $90 \cdot 43$ & $3 \cdot 38$ \\
\hline 同上 $700^{\circ} \mathrm{C}$ 空加熱 & 7876 & 1584 & 0.86 & $80: 17$ & $1 \cdot 25$ & $\mathbf{0}$ & $79 \cdot 78$ & $3 \cdot 09$ \\
\hline 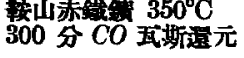 & $73 \cdot 70$ & $4: 38$ & 0 & $89 \cdot 18$ & $\mathbf{0}$ & $\mathbf{0}$ & $89 \cdot 18$ & $2 \cdot 27$ \\
\hline 同上 $700^{\circ} \mathrm{C}^{\circ}$ 空加熱 & $80-84$ & $20: 13$ & 0 & $78 \cdot 10$ & 0 & 0 & $78 \cdot 10$ & $3 \cdot 00$ \\
\hline 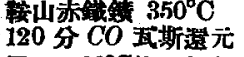 & $71 \cdot 14$ & $2 \cdot 34$ & $35 \cdot 43$ & $56 \cdot 63$ & $51 \cdot 37$ & 0 & 40.63 & $2 \cdot 32$ \\
\hline 同上 $700^{\circ} \mathrm{C}$ 軍空加謷 & $73 \cdot 48$ & $1 \cdot 78$ & $22 \cdot 78$ & $71 \cdot 75$ & 33.02 & 0 & 6151 & $2 \cdot 58$ \\
\hline
\end{tabular}

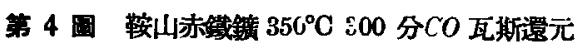
試料直空加熱と導磁育の閣绿

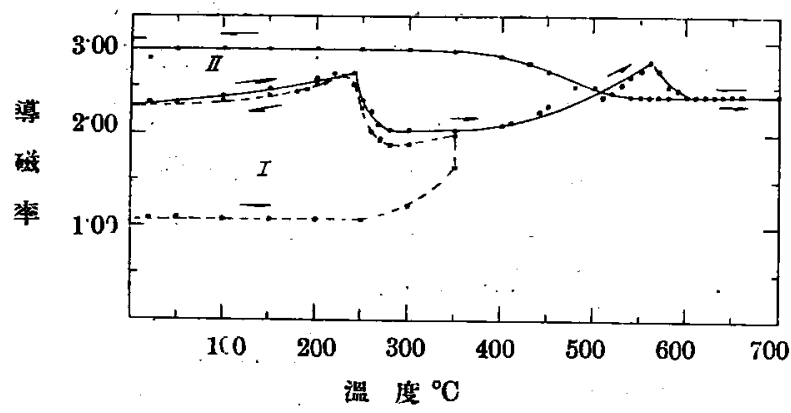

し $400^{\circ} \mathrm{C}$ 上り再び增玑し始め $560^{\circ} \mathrm{C}$ にて最大値を示し。 $600^{\circ} \mathrm{C}$ 亿て少し娍少し以後 $700^{\circ} \mathrm{C}$ 迄は一定でるあ。即ち 本圾料性分析結果上り明かなる如く大部分 $\mathrm{FeO}$ 亿て $600^{3}$

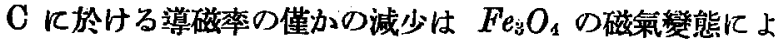
るるのイして $\mathrm{FeO}$ は $700^{\circ} \mathrm{C}$ 迄は磁氣變態をしない。

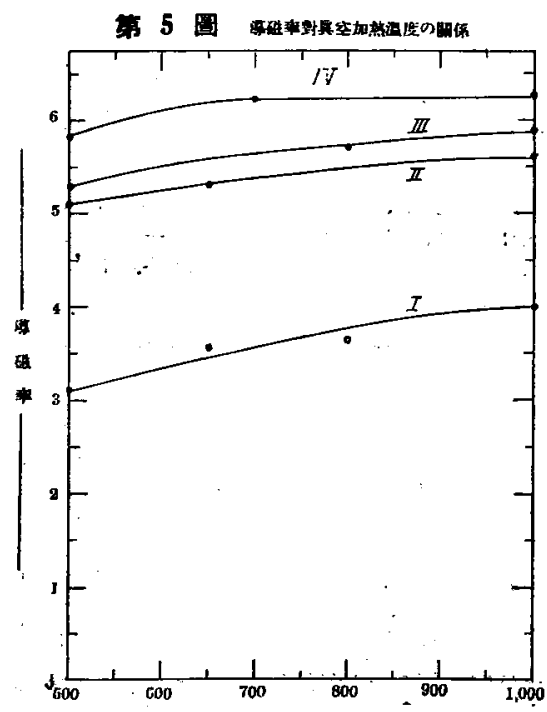

CO 瓦斯摆元 豇料江时多少炭 化物及び遊離桨 素の存在を認め 得べく230 2 C $270 \mathrm{CK}$ 於ける 誉磁本の變化は この炭化物に起 因するものなら ん。との點讲に $\mathrm{FeO}$ の磁莱變 態に關しては後 日詳述すべし。

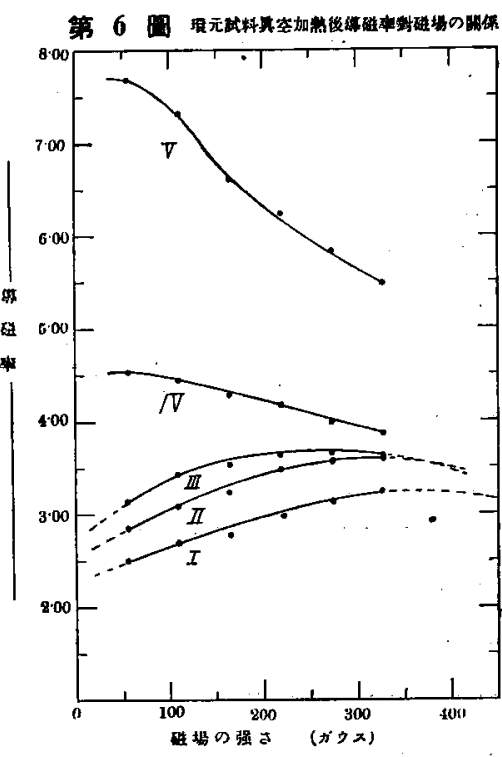

第 4 圆 I は $350^{\circ} \mathrm{C} 250$ 分 $C O$ 瓦斯還元せる場合の罯 元並びに冷却と導磁率の關係を示せるものにして既に前諭 文 ${ }^{1}$ )に詳述せし故說明を省略する。

3. 奧空加熱溫度の影響 既に說明せし如く水素瓦斯還

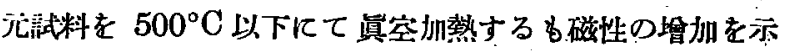
さないが、 $600^{\circ} \mathrm{C}$ 以上加熱する時は增加を示して居る。

西鞍山赤鐵艘 $400^{\circ} \mathrm{C} 200$ 分 $H_{2}$ 瓦斯漫元試料及天然磁 鐵鑛を $650^{\circ} \mathrm{C}, 800 \mathrm{C}, 1,000^{\circ} \mathrm{C}$ に夫ょ 1 時間真空州熱 媵噵磁率を測定すれば第 5 圈の如くなる。(第 6 表 274 ガ ウスの項寥怔)

荋中Ｉは還元試料の場合ＩI. III は本深湖燒富鑛、鞍

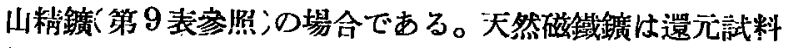
に比して県空加熱に依る導磁率の增加僅少である。650 C

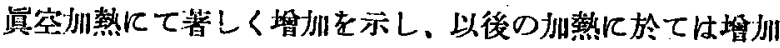
僅少にて 1,000 C 以上は殆んど一定するものと考へられ

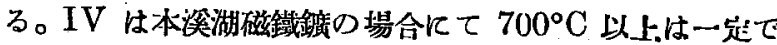
ある。

鞍山赤鐵銿 $400^{\circ} \mathrm{C} 200$ 分 $H_{2}$ 瓦斯還元武料を $650^{\circ} \mathrm{C}$, $800^{\circ} \mathrm{C}, 1,000^{\circ} \mathrm{C}$ に夫k1時間畺空加熱後磁場の强さと䆃 磁率の關係を求むれ代第 6 圆及び第 6 裴の如くなる。

\section{苐 6 表 還元試料貭空加熱绕導磁率對磁場の關俰}

\begin{tabular}{|c|c|c|c|c|c|c|}
\hline 磁場の强さ (カ゚ウス) & & & 咱磁 & $\mu$ & & \\
\hline 種 别 & 55 & 109 & 164 & 219 & 274 & 328 \\
\hline 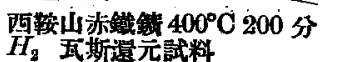 & 250 & 269 & 277 & $2 \cdot 97$ & 3'12 & 324 \\
\hline 同上 $650^{\circ} \mathrm{C} 1$ 時間茸空加熱 & 284 & 3.07 & $3 \cdot 23$ & 347 & 3.56 & 358 \\
\hline 同上 $800^{\circ} \mathrm{C} 1$ 時間戈空加第 & $3 \cdot 14$ & $3 \cdot 43$ & $3 \cdot 53$ & 364 & 365 & 361 \\
\hline 同上 $1,000^{\circ} \mathrm{C} 1$ 時間眞空加熱 & $4 \cdot 54$ & $4: 44$ & $4: 28$ & $4: 17$ & 3.99 & 386 \\
\hline
\end{tabular}




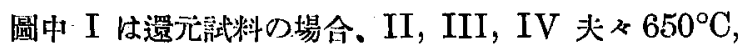

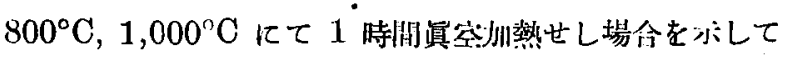
店る。點線は推理により延長せるものである。

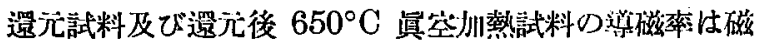

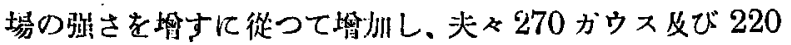
ガウス以上は增加傼少になり夫ね 350 ガウス友び 330 ガ ウス附近にて最大尊磁率を示するのと考へられる $800^{\circ} \mathrm{C}$ 真空加蓺の場合の萛磁率は 180 ガウス迄は磁場の品さと 共に急に埢加し、270 ガウス附近にて最大值を示して昆

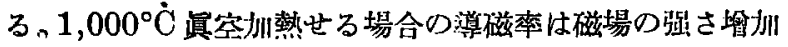
するに從ひ初は緩加に次第に誌に減少し、還元試料州熱前 とは逆の傾向を示して居る。ての場合は 50 ガウス附近に 償磁率聂大の點むりて磁場の强さ垻すに從つて減少して居 るものと洘へられる。

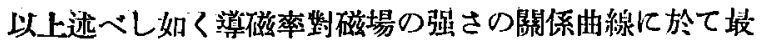
大導碰率を示す點が還元試料の場合は 350 ガウス附近. $650^{\circ} \mathrm{C}$ 真空加熱せる場合は 330 ガウス附近, $8 C 0^{\circ} \mathrm{C}$ 異空 扠熱せる場合は 270 ガウス、 $1,000^{\circ} \mathrm{C}$ 莲空㞦熱の場合に

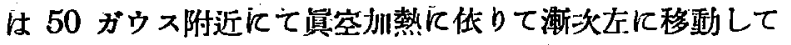

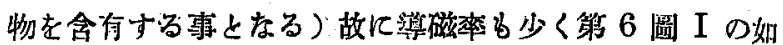

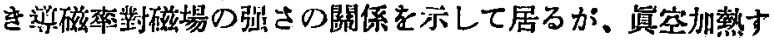
れば酸素結合狀態整倩されて $\mathrm{Fe}_{3} \mathrm{O}_{4}$ 立方能上なり導磁率

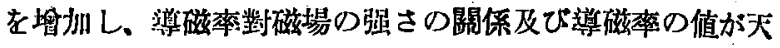

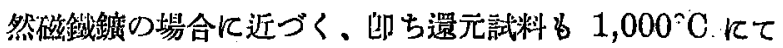

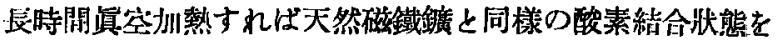

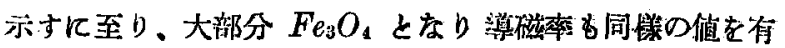
ナるに至るるのと若へられる。

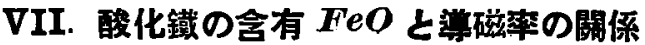

赤鐡鍍を $H_{2}$ 瓦斯、石炭瓦斯、CO 瓦斯にて還元して得 たる酸化鐵及び天然磁性酸化鐵の導磁率を湘起して萝磁來

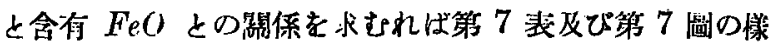
に存る。

圆中 I は還元試料の場合、II は還元試料 $650^{\circ} \mathrm{C}$ 、真空州

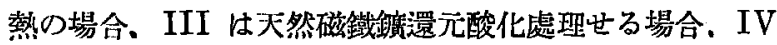
は天然碰鐵鑛の場合、 $\mathrm{V}$ は $\mathrm{Fe}_{2} \mathrm{O}_{3}$ 及び $\mathrm{FcO}$ は全部化合

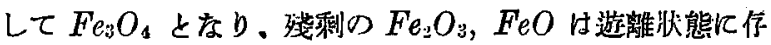
在する理論的場合を考へ。そ心導磁率を $\mathrm{FeO}$ 及び $\mathrm{Fe}_{3} \mathrm{O}$ ， 居るを見る。天然磁鐵

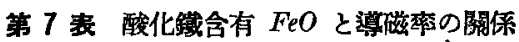

鑑の導磁率轱磁場の强 さの閶係を見るに、V の如く 50 ガウ ス附近 にて最大值を示し以後 磁場の虽さの堆州從 つて念に減少して居る。 前述せる邚く還元試料 の菩磁率と磁場の强さ の關係は苜空㞦熱と其 に漸次天然磁鐵鏣の之 れに近づく傾向を示し て $1,000^{\circ} \mathrm{C}$ 真空玔熱 後は殆んざ同梯の傾向 を示して居る。

還元陚料は單純に $\mathrm{Fe}_{3} \mathrm{O}_{1}$ 立方體となら扒。 後述する如く遊離 $\mathrm{FeO}$ 及ひ固溶 $\mathrm{Fe}$., $\mathrm{FeO}$, $\mathrm{Fe}_{2} \mathrm{O}_{3}$ 索存在して居る (即ち程々の低級酸化

\begin{tabular}{|c|c|c|c|c|c|c|c|c|c|c|}
\hline & \multirow{2}{*}{. 别 } & \multicolumn{4}{|c|}{ 分析結果 } & \multicolumn{3}{|c|}{ 組合結果 } & \multirow[b]{2}{*}{$\mu$} \\
\hline & & & 全践 & 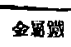 & $\mathrm{Fe}_{2} \mathrm{O}_{3}$ & $\mathrm{FeO}$ & $\widetilde{\mathrm{Fe}_{3} \mathrm{O}_{4}}$ & $\overrightarrow{F e_{2}} O_{B}$ & $\bar{F} e O$ & \\
\hline 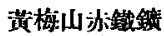 & $3: 0^{\circ} \mathrm{C}$ & 90 分 $H_{2}$ 五斯還元 & 6975 & 0.47 & 8432 & $13 \cdot 26$ & 7275 & 5483 & - & $1 \cdot 70$ \\
\hline & $400^{\circ} \mathrm{C}$ & 90 分 $H_{2}$ 成斯逗元 & $71 \cdot 36$ & 061 & 7279 & $25 \cdot 52$ & $82 \cdot 25$ & 16.06 & - & $2 \cdot 36$ \\
\hline & & & $71 \cdot 92$ & 0.45 & 72.85 & 2640 & 85.08 & $14: 17$ & - & 249 \\
\hline 㟶梅山㴒鐵全 & $400^{\circ} \mathrm{C}$ & 250 分 $H_{2}$ 五澌邉元 & $7 I^{\prime} 61$ & 1.00 & $65.29^{\circ}$ & $32 \cdot 10$ & $94 \cdot 65$ & - & 274 & $2 \cdot 81$ \\
\hline 元鞍山亦鐵鋽 & $4 C 0^{\circ} \mathrm{C}$ & 100 分 $H_{2}$ 瓦斯㯰元 & $71 \cdot 38$ & $2 \cdot 19$ & $61 \cdot 67$ & 33.53 & $89 \cdot 42$ & - & 5.78 & $2 \cdot 70$ \\
\hline 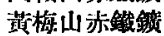 & $350^{\circ} \mathrm{C}$ & 680 分 $H_{3}$ 瓦斯還元 & 7179 & 131 & 61.98 & 3542 & 89.42 & - & $7 \cdot 56$ & 273 \\
\hline 同 & $406^{\circ} \mathrm{C}$ & 645 分 $H_{2}$ 瓦斯還元 & $72: 51$ & 5.08 & 5459 & $37 \cdot 63$ & $79 \cdot 15$ & - & 1307 & $3: 10$ \\
\hline 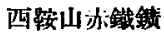 & $456^{\circ} \mathrm{C}$ & 石宸五斯遭元 & $71 \cdot 40$ & $2 \cdot 07$ & $57 \cdot 49$ & $37 \cdot 50$ & $83 \cdot 35$ & - & $11 \cdot 62$ & $2 \cdot 90$ \\
\hline 同] & $400^{\circ} \mathrm{C}$ & 200 分 $H_{2}$ 瓦斯還元 & $71 \cdot 68$ & $2 \cdot 23$ & $56^{\circ} 10$ & 38.87 & $81 \cdot 34$ & - & $13 \cdot 62$ & 3.12 \\
\hline 同 & $400^{\circ} \mathrm{C}$ & 160 分石炭巩斯邆元 & $71 \cdot 18$ & 164 & $55 \cdot 19$ & 39.80 & 8020 & - & 1497 & 272 \\
\hline 同 & $400^{\circ} \mathrm{C}$ & $\varepsilon 0$ 分 $C O$ 五斯遦元 & $71 \cdot 72$ & 1.42 & 46.72 & $48 \cdot 40$ & $67 \cdot 74$ & - & $27 \cdot 40$ & $2 \cdot 39$ \\
\hline 问 & $350^{\circ} \mathrm{C}$ & 250 分 $C O$ 瓦斯僄元 & $\mathbf{7 4 . 0 4}$ & 1.56 & 7.99 & $86 \cdot 05$ & $11 \cdot 59$ & - & $82 \cdot 45$ & $2 \cdot 18$ \\
\hline 阔 & $350^{\circ} \mathrm{C}$ & 300 分 $C O$ 瓦斯逼元 & 7370 & $4: 38$ & - & $89 \cdot 18$ & - & - & $89 \cdot 18$ & $2 \cdot 27$ \\
\hline 同 & $350^{\circ} \mathrm{C}$ & 120 分 $C O$ 五斯逑元 & $71 \cdot 74$ & $2 \cdot 34$ & $35 \cdot 43$ & $56 \cdot 63$ & $51 \cdot 37$ & - & 4068 & $2 \cdot 32$ \\
\hline 同 & $400^{\circ} \mathrm{C}$ & 250 分 CO 五斯還元 & $73 \cdot 02$ & 210 & $2 \cdot 60$ & $91 \cdot 60$ & 377 & - & $90 \cdot 43$ & $2: 32$ \\
\hline \multicolumn{11}{|c|}{ 還元試料悳空加熱: 一 } \\
\hline 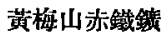 & $350^{\circ} \mathrm{C}$ & 90 分 $H_{2}$ 瓦斯還元 & 7083 & $0 \cdot 38$ & $85 \cdot 23$ & 13.94 & 44.94 & $54: 23$ & - & 2.08 \\
\hline & $400^{\circ} \mathrm{C}$ & 90 分 $H_{\mathrm{s}}$ 瓦斯還元 & $71 \cdot 90$ & 027 & 7279 & 2666 & 85.91 & 1354 & - & 355 \\
\hline & $400^{\circ} \mathrm{C}$ & 240 分 $H_{2}$ 瓦斯遥元 & $71 \cdot 79$ & 020 & $68 \cdot 08$ & 30.85 & 9868 & - & 0.24 & $3 \cdot 97$ \\
\hline 鞍山於鐵 銑 & $400^{\circ} \mathrm{C}$ & 200 分 $H_{2}$ 瓦断息元 & $71 \cdot 69$ & 082 & 60.69 & $36: 56$ & $87 \cdot 90$ & - & $9 \cdot 26$ & 381 \\
\hline 间 & $\begin{array}{l}356^{\circ} \mathrm{C} . \\
700^{\circ} \mathrm{C}\end{array}$ & $\begin{array}{l}120 \text { 分 } C O \text { 瓦斯罯元 } \\
\text { 椇空加熱 }\end{array}$ & 7348 & 173 & 2278 & $71 \cdot 75$ & 33.02 & - & $61 \cdot 51$ & 2.53 \\
\hline \multicolumn{11}{|c|}{ 天然磁 驖 鑛: 一 } \\
\hline 本 溪 湖 & 磁 践 & 䤮 & 7185 & - & $68 \cdot 46$ & 30.84 & $99 \cdot 26$ & - & 0.04 & 588 \\
\hline 大厥 灌 & 磁 & 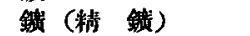 & $63 \cdot 98$ & - & 66.36 & 3260 & 7283 & $16: 13$ & - & $4: 47$ \\
\hline 大 嵌 清 & 磁 驖 & 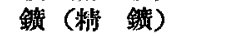 & 6171 & - & 6378 & 2200 & 70.90 & $14 \cdot 88$ & - & $4 \cdot 40$ \\
\hline 本溪湖磁鐵鍇 & $700^{\circ} \mathrm{C}$ & 空空加熱 & $71 \cdot 89$ & - & 68.46 & 30.89 & $99 \cdot 26$ & - & 0.09 & 623 \\
\hline \multicolumn{11}{|c|}{ 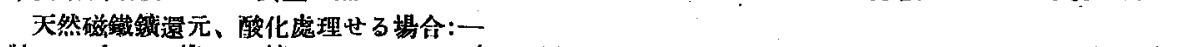 } \\
\hline 山 & 榭 & 籍 & $72 \cdot 26$ & - & 68.93 & $30 \cdot 94$ & $99 \cdot 71$ & 0.16 & - & $5 \cdot 30$ \\
\hline 本 溪，湖 & 烧， & & $71 \cdot 92$ & - & 6893 & $30 \cdot 50$ & $98 \cdot 29$ & $1 \cdot 14$ & - & $5 \cdot 11$ \\
\hline 鞍 山精鍇 & $1,000^{\circ} \mathrm{C}$ & 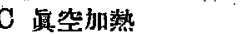 & $72 \cdot 18$ & - & $68: 36$ & $31 \cdot 35$ & 9912 & - & $0 \cdot 59$ & 588 \\
\hline 本溪湖燒富鑑 & $1, c 00$ & $\mathrm{C}$ 匍空加熹 & $71 \cdot 94$ & $\div$ & $68 \cdot 74$ & 3070 & 98.93 & 0.51 & $=$ & 5.61 \\
\hline
\end{tabular}




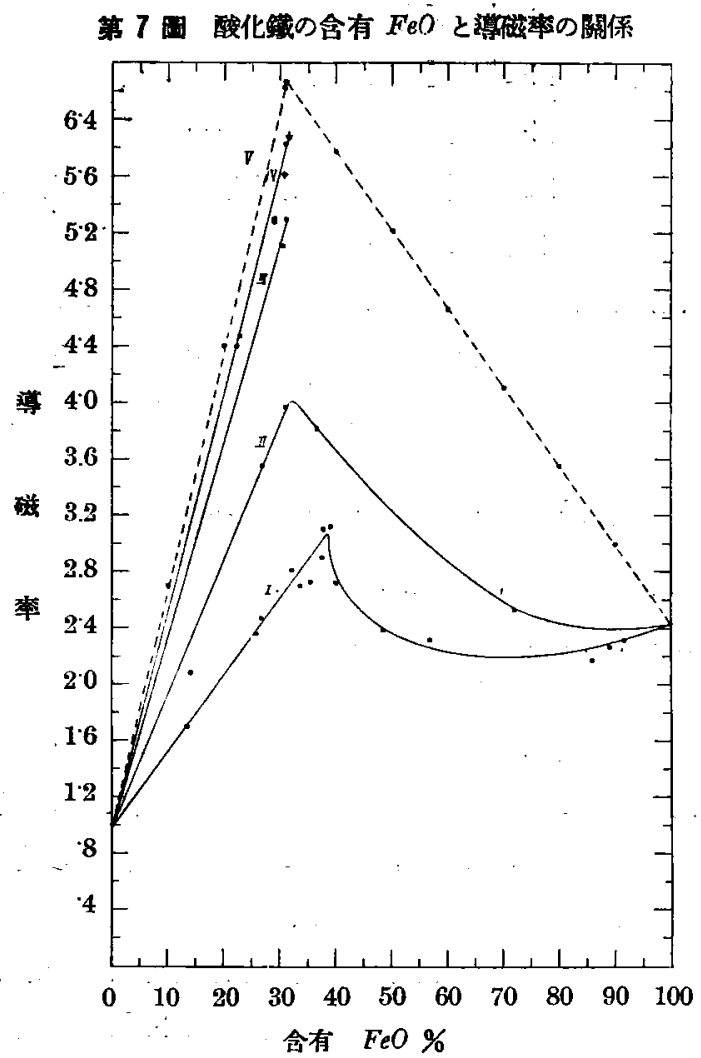

の導磁來より(2) 式とより計算して得た第 8 表の值を圖 示せるすのでるる。郎ち $\mathrm{V}$ の場合性 $\mathrm{Fe}_{3} \mathrm{O}_{4}-\mathrm{Fe}_{2} \mathrm{O}_{3}$ 及び

\begin{tabular}{|c|c|c|c|c|c|}
\hline 8 叟 & $\begin{array}{l}\text { 理滥的 } \\
\mathrm{FeO}\end{array}$ & 洁合㖣 & & & $\begin{array}{l}\mathrm{Fe}_{3} \mathrm{O}_{1}-\mathrm{FeO} \text { t夫 } \\
\text { \&單體混合混合物 }\end{array}$ \\
\hline & & 誦的組 & & 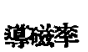 & とせる場合 \\
\hline & $\mathrm{Fe}_{\mathrm{B}} \mathrm{O}_{4}$ & $\mathrm{FeO}$ & $\begin{array}{ll}\mathrm{Fe}_{2} \mathrm{O}_{3} \\
\mathrm{~B} 78\end{array}$ & $\mu$ & \\
\hline 20 & $\begin{array}{l}32 \cdot 2 \\
64 \cdot 4\end{array}$ & $\overline{-}$ & $\begin{array}{l}67.8 \\
35.6\end{array}$ & $\begin{array}{l}270 \\
4: 40\end{array}$ & \\
\hline & 100 & - & - & & 磁率を坦加し、 31 \\
\hline 40 & 87 & 13.0 & $\bar{z}$ & $\begin{array}{l}5 \cdot 7 \\
5.2\end{array}$ & $\% \mathrm{FeO}$ 郎与全部 \\
\hline & 78 & $\begin{array}{l}260 \\
42.0\end{array}$ & - & $x$ & 立方 \\
\hline 70 & & & & & \\
\hline 80 & 29 & & - & & 行る時に耳 \\
\hline & 145 & & & & \\
\hline & & & & & \\
\hline
\end{tabular}

$\mathrm{FeO}$ 量の堵加と共に直線的に減少して居る。之れ假想線 である。

還元詁料の導磁率對合有 $\mathrm{FeO}$ の關係恃理論的場合と趣 を異にし. 圖中 I の如く最初直線的に導磁率を增加し 38 $\% \mathrm{FeO}$ 凡て最大導磁率を示し以後 $\mathrm{FeO}$ の㙁加と共に急 に減少し. $70 \% \mathrm{FeO}$ 附近にて最小值を示し、以後再び少 し增加して居る。還元陚料を眞空加熱する時は II の如く 變化す。郎古還元試料にては一部 $\mathrm{Fe}_{2} \mathrm{O}_{3}, \mathrm{FeO}$ は遊離又 は固溶體として存在し磁性を示ささるる。加熱に上り酸素 結合狀態整備され $\mathrm{F}_{3} \mathrm{O}_{3} \mathrm{O}$ ，の立方體を得名が故で西る。導

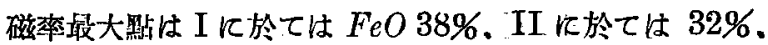
III，IV は $31 \%$ 亿て濑次理論的場合の $31 \%$ 反接近し。

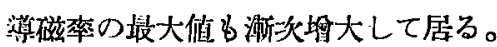

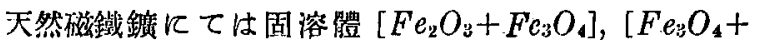
$\left.\mathrm{Fe}_{2} \mathrm{O}_{3}\right],\left[\mathrm{Fe}_{3} \mathrm{O}_{4}+\mathrm{FeO}\right]$ を考入得へくこの固溶體の䉆め にIVの如く同じ $F e O$ 含有量に對してVの場合上口低 き学磁率を示して居る。

鞍山精鏣及び本滛湖燒富鐄は共に還元酸化處理せるもの そして天然磁鐵鑛より尊磁率少くIII の如くなり。天然磁

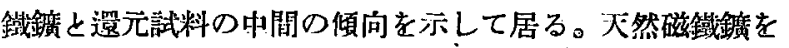
$700^{\circ} \mathrm{C}$ 真空加熱すれば固溶體仙解離作用を起し 理論的結 合状態を示すに至り祘磁來對含有 $\mathrm{FeO}$ の關係は V 亿接

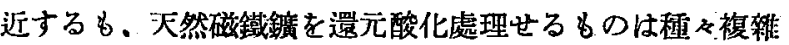
なる絬合狀態を示し $800^{\circ} \mathrm{C}$.加熱にてを理論的状態を示さ す、加熱に上り潮次接近して $1,000^{\circ} \mathrm{C}$. 加熱後は天然磁鐵 鑛の遖線 IV,の上一乘る樣になる。

酸化鐵の薄磁率對含有 $\mathrm{FeO}$ の關係は理論的全部 $\mathrm{Fe}_{3} \mathrm{O}_{4}$ 立方體を形成すればＶの如く變化すべきであるが、一般 に天然磁鐵鉷及び還元試料に於ては.單純に $\mathrm{Fe}_{3} \mathrm{O}_{4}$ 方立體 を存さず吹章にて詳迅する如く種々の固溶體を形成し、分 析組合上の $\mathrm{Fe}_{3} \mathrm{O}_{4} \%$ 上り著しく導磁來小にして還元試料 は $38 \% \mathrm{FeO}$ の場合、天然磁鉝鏣は $31 \% \mathrm{FeO}$ にて最大 導磁來を示して理論的の場合とは趣を異にして居るが。て れを $650^{\circ} \mathrm{C}$ 以上筫空加熱すれば 固液體は解離作用を起し $\mathrm{Fe}_{3} \mathrm{O}_{4}$ 立少體在形成して導磁率を增し。漸次理淪的場合 $\mathrm{V}$ 凡接近ナる傾向を示して居る。

\section{VIII. 酸素結合狀態と固溶體}

酸化鐵の存在し得る狀態を舉ぐれば次の如しっ。

天然完全化合菜

1. $\mathrm{Fe}_{2} \mathrm{O}_{3}$ 非碰性科方晶系

2. $\mathrm{Fe}_{3} \mathrm{O}_{4}$ 磁性正方晶系

天然固溶體系

3. $\left[\mathrm{Fe}_{2} \mathrm{O}_{3}+\mathrm{Fe}_{3} \mathrm{O}_{4}\right]$ 非磁性科方晶系

4. $\left[\mathrm{Fe}_{3} \mathrm{O}_{4}+\mathrm{Fe}_{3} \mathrm{O}_{3}\right]$ 磁性正方晶系 Martite 還元に上り生扣る固溶體系

5. $\left[\mathrm{Fe}_{3} \mathrm{O}_{4}+\mathrm{FeO}\right]$ 磁性正方晶系 -

6. $\left[\mathrm{Fe}_{2} \mathrm{O}_{3}+\mathrm{FeO}\right]$ 非磁性斜方晶系

7. $\left[\mathrm{FeO}+\mathrm{Fe}_{3} \mathrm{O}_{4}\right]$ 弱磁性正方晶系

8. $\left[\mathrm{F}_{3} \mathrm{O}_{4}+\mathrm{F}^{\prime} \mathrm{e}\right]-\mathrm{z}_{\mathrm{m}}$ 性方晶系 
9. $[\mathrm{FeO}+\mathrm{Fe}]$ 弱磁性正方晶系

10. $[\mathrm{Fe}+\mathrm{Fe} \mathrm{O}]$ 磁牲正方晶系 天然單體として考へ得る酸化彇態

11. $\mathrm{Fe}_{2} \mathrm{O}_{3} ; \mathrm{Fe}_{3} \mathrm{O}_{4}$ 搯元により單體として考入得る酸化状態

12. $\mathrm{Fe}_{3} \mathrm{O}_{4} ; \mathrm{Fe}_{2} \mathrm{O}_{3} ; \mathrm{FeO}$

13. $\mathrm{Fe}_{3} \mathrm{O}_{4}-\mathrm{FeO}$ 低級酸化物

14. $\mathrm{FeO}-\mathrm{Fe}$ 低級酸化物

還元後道空加熱に上り固溶體よ口分離し得る單熊

15. $\mathrm{Fe}_{2} \mathrm{O}_{3} ; \mathrm{Fe}_{3} \mathrm{O}_{4} ; \mathrm{FeO}$. 磁性正方晶系

本實驗の結果酸化鐵の化命爿態を㳄の如く推諭し得る。

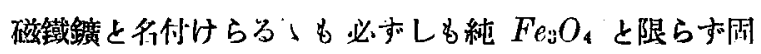
溶體 $\left[\mathrm{Fe}_{2} \mathrm{O}_{3}+\mathrm{Fe}_{3} \mathrm{O}_{4}\right],\left[\mathrm{Fe}_{3} \mathrm{O}_{4}+\mathrm{Fe}_{4} \mathrm{O}_{3}\right],\left[\mathrm{Fe}_{3} \mathrm{O}_{4}+\mathrm{FeO}\right]$

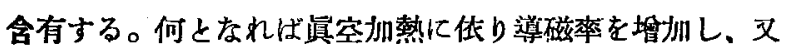
磁境對導磁率曲線を變化する事上り明かである。本溪湖磁 鐵鈸は本實驗にて得られた最純試料で、更に $700^{\circ} \mathrm{C}$ 真空 加熱せるるのは最り安定せる酸素結合狀態である。本賽驗 にて得られたる結果天然磁鐵鑛の本質は次の如きものとな 々。

陚料分析結果 全鐵 $71 \cdot 89 \quad \mathrm{Fe}_{3} \mathrm{O}_{4} \quad 99 \cdot 26$

最大薄磁率 55 ガウス磁場にて $\quad 8.12$

274 ガウス磁場に於ける薄碰率

$6 \cdot 23$

整山精鑛、本溪湖燒富鏣は大部分 $\mathrm{Fe}_{3} \mathrm{O}_{4}$ の結合狀態に 西るは明かなるる還元及づ酸化處理により一部結合狀態變 化せる䉆導磁率を減少して居る。之等を對照して伱在を推 理し得る。

$\mathrm{Fe}_{2} \mathrm{O}_{3}$ ¿ $\mathrm{FeO}$ 性化合する時完全飞 $\mathrm{Fe}_{2} \mathrm{O}_{4}$ を形成する 6.

$\mathrm{Fe}_{3} \mathrm{O}_{4}$ 磁栍正方晶系 $\rightleftarrows \mathrm{Fe}_{3} \mathrm{O}_{3} \cdot \mathrm{F} e \mathrm{O}$

$$
\begin{aligned}
& \rightleftarrows\left[\mathrm{Fe}_{2} \mathrm{O}_{3}+\mathrm{Fe}_{3} \mathrm{O}_{4}\right] \text { 非磁悝科方晶系 } \\
& \rightleftarrows\left[\mathrm{Fe}_{8} \mathrm{O}_{4}+\mathrm{Fe}_{2} \mathrm{O}_{8}\right] \text { 稵性正方晶系…......(2) }
\end{aligned}
$$

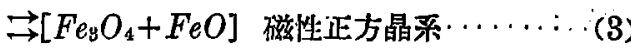

$$
\begin{aligned}
& \rightleftarrows\left[\mathrm{FeO}+\mathrm{Fe}_{3} \mathrm{O}_{\mathrm{d}}\right] \text { 弱磁性正方晶系……(4) } \\
& \rightleftarrows \mathrm{Fe}_{3} \mathrm{O}_{4} \text { 十遊離 } \mathrm{FeO}
\end{aligned}
$$

の如く存在し得。天然磁鐵鏣は (1)(2)(3) の形反て存在

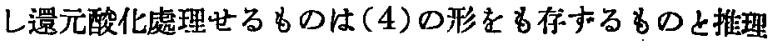
し得。 $\mathrm{F} \epsilon \mathrm{O}$ は不安定なれば・天然狀熊てては遊離 $\mathrm{FeO}$ は 存在し得叔。

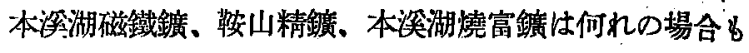
分析組合結果は殆んど同様であるが、(第 9 裴餐照) 薄磁 率は著しく異つて居る。

てれは磁鐵鈸の導磁來は $\mathrm{Fe}_{3} \mathrm{O}_{4}$ 磁性正方晶系に依る る のとして前三背は皆酸素結合狀態を異てし、乙の $\mathrm{Fe}_{3} \mathrm{O}_{4}$ の量異つて居る䳕である。郎ち $\mathrm{Fe}_{3} \mathrm{O}_{4}$ の導磁率を 6.27 と して天然磁鐵鏣中の $\mathrm{Fe}_{3} \mathrm{O}_{4}$ 量を(2) 式により計算し酸素 結合狀態を推理すれば第 9 表の如くなる、郎ち何れの場合 表に示す如く $\mathrm{Fe}_{3} \mathrm{O}_{4}$ 立方體の量は組合結果より少なく 殘剩の $\mathrm{FeO}$ 及び $\mathrm{Fe}_{2} \mathrm{O}_{3}$ 生固溶體 $\left[\mathrm{Fe}_{2} \mathrm{O}_{3}+\mathrm{Fe}_{3} \mathrm{O}_{4}\right]$ 及代 $\left[\mathrm{Fe}_{3} \mathrm{O}_{4}+\mathrm{FeO}\right]$ として存在するものと推理される。600 以上真空加熱する時はての固溶體解離作用を起し、强磁性 $\mathrm{Fe}_{3} \mathrm{O}_{4}$ 立方體を形成し磁性を增加して居る。

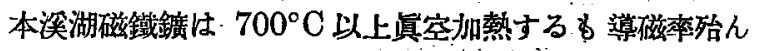
ぼ變化なく.700 $\mathrm{C}$ 亿て全部 $\mathrm{Fe}_{3} \mathrm{O}_{4}$ 亿結合するものと推

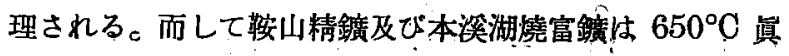

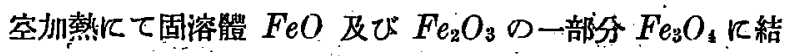
合するのみにて势熱溫度上昇につれ漸㳄結合して磁性を增 し J, $000^{\circ} \mathrm{C}$ 亿てる份多少 $\mathrm{FeO}$ 及び $\mathrm{Fe}_{2} \mathrm{O}_{3}$ を固溶體とし て殘存して居るものと推理される。前速せし如く $1,000^{\circ} \mathrm{C}$

第 9 天然磁鐵鈸及び還元試料酸素結合狀熊

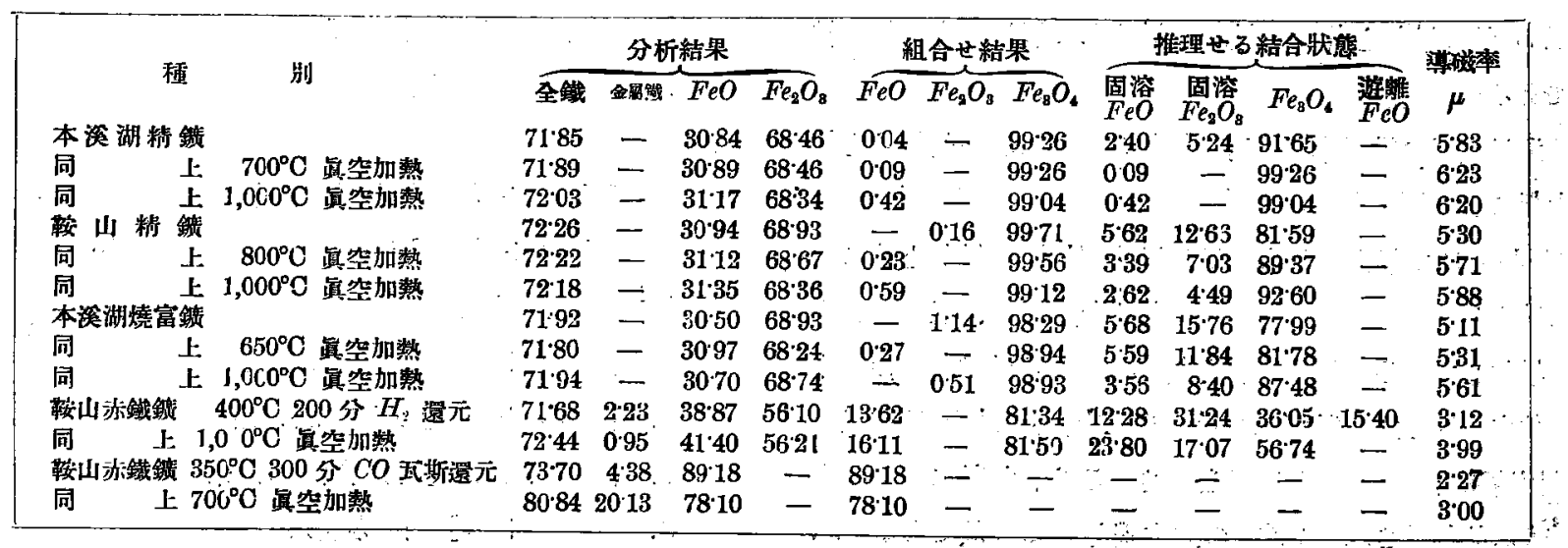




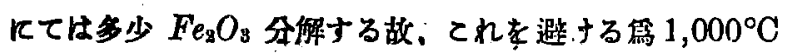

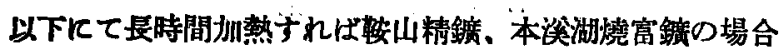

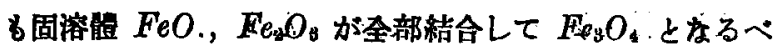
をである

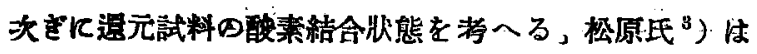

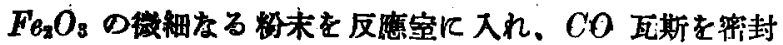
して一定溫度に長時間反應を起さすれば最初 $F^{2} e_{2} O_{3}$ と $\mathrm{Fe}_{3} \mathrm{O}_{4}$ の固溶體成生し酸化鐵中の酸素の量 $800 \% \mathrm{C}$ の時 28 $\%\left(\mathrm{Fe}_{3} \mathrm{O}\right.$ 、性酸素量 $\left.27.6 \%\right)$ 飞減少すれば $\mathrm{FeO}$ が出來て

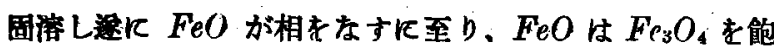
和しててK $\mathrm{Fe}\left(\mathrm{O}\right.$ 中曰 $\mathrm{Fe}_{3} \mathrm{O}_{1}$ 固溶體と $\mathrm{Fe}_{3} \mathrm{O}_{4}$ 叫飞於ける

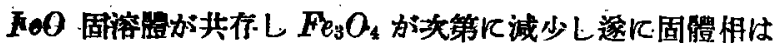

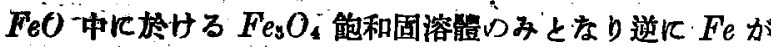
出來て $\mathrm{FeO}$ む以て飽和した $\mathrm{F} \bar{e}$ と $\mathrm{FeO}$ を以て能和した $\mathrm{FeO}$ との二種の固溶體が存在L $\mathrm{FeO}$ が次第に減少し遂に $\mathrm{Fe}$ 中儿於ける $\mathrm{FeO}$ 鸽和固溶體のみ上なり，てれより後

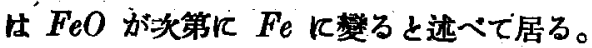

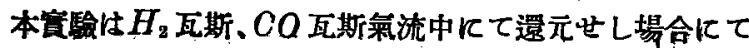

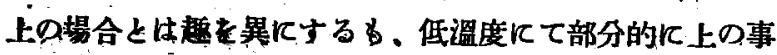

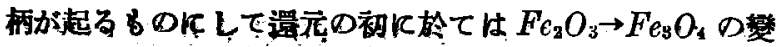
化起 9，一部 $\mathrm{Fa}_{3} \mathrm{O}_{4} \rightarrow \mathrm{FeO}$ の變化進行しても $\mathrm{FeO}$ \&大 部分 $\mathrm{Fe}_{2} \mathrm{O}_{4}$ K固溶さ机磁性は主飞 $\left[\mathrm{Fe}_{3} \mathrm{O}_{4}+\mathrm{FeO}\right]$ 固溶體

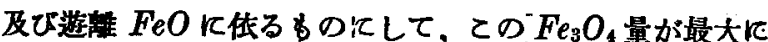

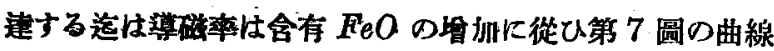
I k示如く道線的飞坦加するが。更飞 FeO 增し一部分

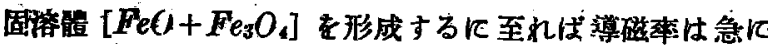

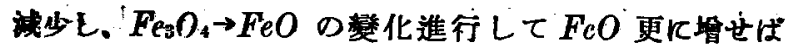
$\mathrm{Fe}_{3} \mathrm{O}_{4}$ 㤌全部固溶され曲線 I 凡示す如く敷磁率最小を示

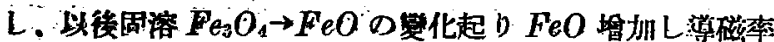

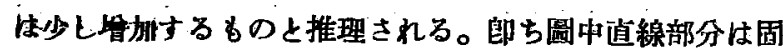
溶體 $\left[\mathrm{Fe}_{2} \mathrm{O}_{3}+\mathrm{Fr}_{3} \mathrm{O}_{4}\right],\left[\mathrm{Fe}_{3} \mathrm{O}_{4}+\mathrm{Fe}_{-} \mathrm{O}_{3}\right],\left[\mathrm{Fe}_{3} \mathrm{O}_{4}+\mathrm{FeO}\right]$ 及

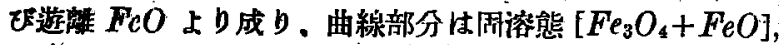
$\left[\mathrm{FeO}+\mathrm{Fe}_{3} \mathrm{O}_{4}\right],[\mathrm{Fe} \mathrm{O}+\mathrm{Fe}]$ 上り成るこさ示して居る。

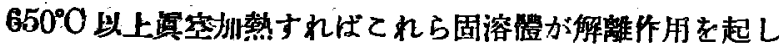
理論的磁性を宗亡導磁本增加し最大導磁率を示す $\mathrm{FeO} \%$

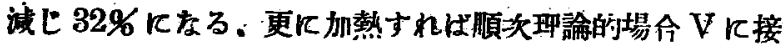
近すへ施である。

以上の事唡上り明かなる如く各種還元てて得られる酸化

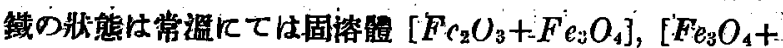
$\left.F^{\prime}{ }^{2}{ }_{2} \mathrm{O}_{3}\right],\left[\mathrm{Fe}_{3} \mathrm{O}_{4}+\mathrm{Fe} \mathrm{O}\right],\left[\mathrm{F}, \mathrm{O}+\mathrm{F}_{3} \mathrm{O}_{4}\right],\left[\mathrm{F}_{1} \mathrm{O}+\mathrm{Fe}\right]$ 及び

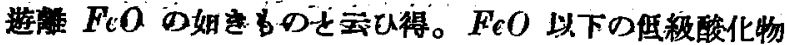

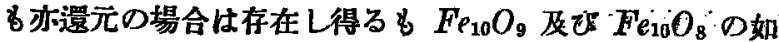

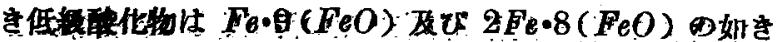

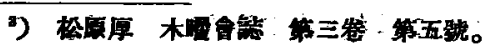

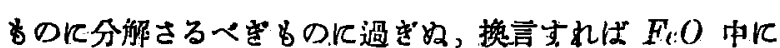

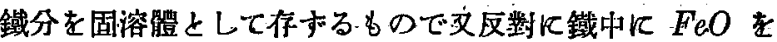
固溶澧として存するものである。本資驗の場合忙還元鐵校 めてて少き第め $\mathrm{FeO}$ 側を主體となし得る。

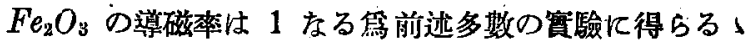
導磁率值は $\mathrm{Fe}_{3} \mathrm{O}_{4}$ 及び $\mathrm{FeO}$ の混合澊磁率である。

酸化鐵の形は。

$$
\begin{array}{r}
\mathrm{x} \mathrm{Fe}_{2} \mathrm{O}_{3} \cdot \mathrm{y} F e \mathrm{O} \text { 郎方 } \times \mathrm{Fe}_{3} \mathrm{O}_{4} \cdot(\mathrm{y}-\mathrm{x}) \mathrm{FeO} \\
\text { 或は } \mathrm{Fe}_{(2 \mathrm{x}+\mathrm{y})} \mathrm{O}_{(\mathrm{3x}+\mathrm{y})}
\end{array}
$$

の奶く㫶着する。

$$
\begin{array}{lc}
\mathrm{x}=1 . & \mathrm{y}=1 \quad \text { の場合には } F_{e ;} O_{4} \text { となり } \\
\mathrm{x}>\mathrm{y} & \text { の場合には低還元 - } \\
\mathrm{x}<\mathrm{y} & \text { の場合には過剩還元をなる。 }
\end{array}
$$

高溫度にて $\mathrm{FeO}$ は $\mathrm{Fe}_{2} \mathrm{O}_{3}$ ～と完全化合物を作り。過剕

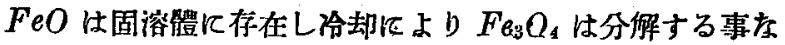
く $\mathrm{FeO}$ は $220^{\circ} \mathrm{C}$ 亿て一部遊離状態となる事は前實駼に て確め得た。又化合狀態にある $\mathrm{Fe}_{3} \mathrm{O}_{4}$ は 6300 ○於て碳

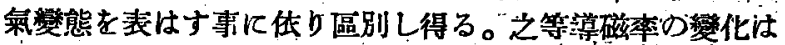
夫ょ存在量に上り變化する事も前述の諸點により示されで 居る。

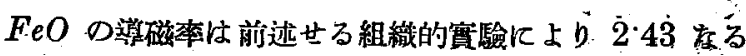
事證朋せらるつが故に之等の理論を總活して處理試料の酸 化鐵の結合狀態を決定すれば第 9 表の如くなる。第 9 表は 還元試料の導磁來は遊蜼 $\mathrm{FeO}$ 及び $\mathrm{F}_{3} \mathrm{O}_{4}$ 几依るものと

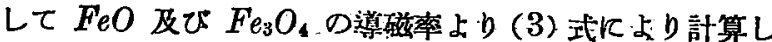
た結果である。 $400^{\circ} \mathrm{C} H_{2}$ 瓦斯還元試料飞就き計算例を示 せば次の如し。

乙の場合遊離 $\mathrm{FeO}$ は後述する如く $15 \cdot 4 \%$ となる故、 $\mathrm{Fe}_{2} \mathrm{O}_{4}$ として存在すべき量を $\mathrm{x \%}$ とすれば(3)式上り

$$
\begin{aligned}
(6 \cdot 27-1) & \frac{x}{100}+(2 \cdot 43-1) \\
x & =36 \cdot 05 \%
\end{aligned}
$$

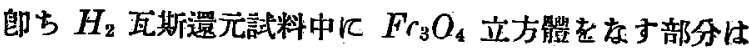
$36.05 \%$ Kして分析組合結果の $\mathrm{Fe}_{3} \mathrm{O}_{4}$ 量に比し著しく少 く 、後述与る如く $15.4 \% \mathrm{FeO}$ は遊踓议態存在し残剩の $\mathrm{FeO}$ 及び $\mathrm{F}_{\mathrm{C}_{2}} \mathrm{O}_{3}$ は固塎體 $\left[\mathrm{F}^{\prime} \mathrm{e}_{2} \mathrm{O}_{3}+\mathrm{Fe}_{3} \mathrm{O}_{4}\right]$ 及び $\left[\mathrm{F}_{e_{3}} \mathrm{O}_{4}+\right.$

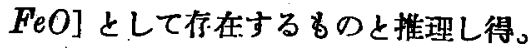

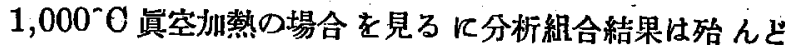

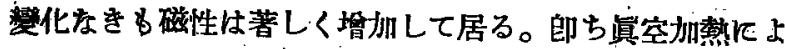
b固溶體は解離作用老起し $\mathrm{Fe}_{3} \mathrm{O}_{4}$ 立方體を形成し磁性 增加するもの推理される。從つて $\mathrm{Fe}_{3} \mathrm{O}_{4}$ 立方體曾加L 遊離 $\mathrm{FeO}$ は再ひ固溶するものと考へられる。ての窟めに

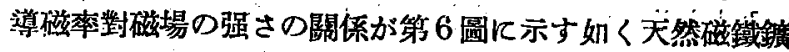

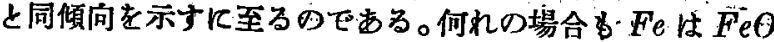
と固溶して居るものと考へられる。 
$H_{2}$ 瓦斯還元試料索冷却すれば第 8 圖 $\left.{ }^{1}\right) \mathrm{I}$ の如く最初は 酎磁率直線的に減少し $200^{\circ} \mathrm{C}$ 上り再び增州し、酸化す

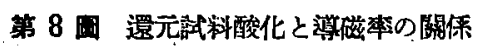

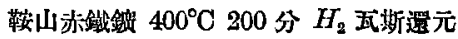

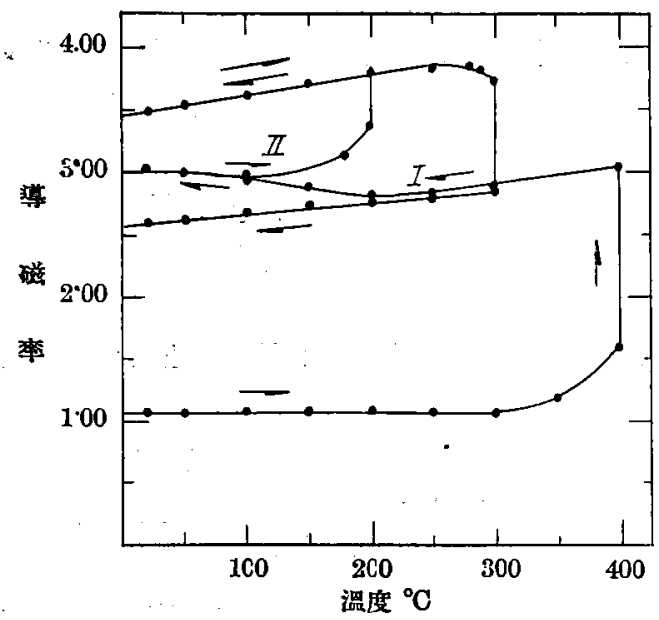

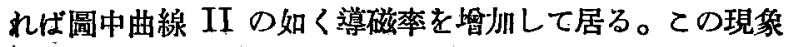
考冷却の際 $200^{\circ} \mathrm{C} K \tau F \mathrm{O}$ 遊離し酸化の際 $200^{\circ} \mathrm{C}$ 附近 行弱磁性 $\mathrm{FeO} \rightarrow$ 强磁性 $\mathrm{Fe}_{3} \mathrm{O}$ ，の變化起るに依る bの上 して $\mathrm{FeO}$ 及び $\mathrm{Fe}_{2} \mathrm{O}_{4}$ の導磁率より数字的に說明すれば 次の如くなる。

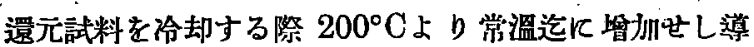
磁卒は $3 \cdot 04-2 \cdot 82=0.22$

この㫮加量を $\mathrm{FeO}$ の分離に依るるの上假定すれば $\mathrm{FeO}$ 量は:

$$
1 \times \frac{0.22}{2 \cdot 43-1} \times 100=15.4 \%
$$

$200^{\circ} \mathrm{C}$ にて酸化して全部 $\mathrm{Fe}_{3} \mathrm{O}_{4}$ にあると假定与れば

$$
15.7 \times \frac{232}{216}=16.5 \%
$$

$16.5 \% \mathrm{Fe}_{3} \mathrm{O}_{4}$ の增扣に對する導磁率の增加量は $\mathrm{Fe}_{3} \mathrm{O}_{4}$ の導磁率を 6.27 をすれば次の如くなる。

$(6.27-1) \times 0.165=0.87$

還元試料を酸化する際の導磁率の賭州量は實驗にては $0 \% 97$ にて上の值に近をを見る。郎ち還元試料には $15 \%$ の $\mathrm{FeO}$ が遊離狀態に存在しこれが酸化して既に前報告に 述二し如く弱磁性 $\mathrm{FeO} \rightarrow$ 强磁性 $\mathrm{Fe}_{3} \mathrm{O}_{\mathrm{a}} \rightarrow$ 强磁性 $\mathrm{Fe}_{2} \mathrm{O}_{3}$ の

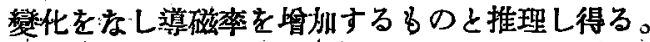

CO 瓦斯還元試料は一部炭化物及び遊離岁素を䏡在する 女大部分 $\mathrm{FeO}$ にて金虽鐵及び $\mathrm{F}_{3} \mathrm{O}_{4}$ は $\mathrm{FeO}$ 亿固溶し て居るものと考へられる，CO 瓦斯 $350^{\circ} \mathrm{C} 120$ 分還元試 料には固溶䌡 $\left[\mathrm{Fe}_{3}^{\prime} \mathrm{O}_{4}+\mathrm{FeO}\right],\left[\mathrm{FeO}+\mathrm{Fe}_{2} \mathrm{O}_{4}\right]$ が存在する

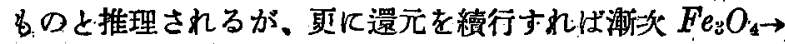
$E e O D$ 變化隻行して 300 分還元後は固溶體 $\left[F e O+F e e_{5}\right]$ のみとなる。畺空加熱すれば炭化物及び一部 $\mathrm{FeO}$ は分解 して金屬鐵を增加し、金屬鐵は遊離するに至る。

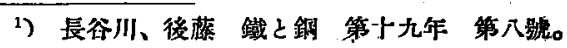

IX. 總 括

以上の結果を維括すれ狆次の如くなる。

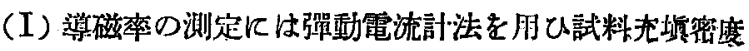
を $265 \mathrm{gr} / \mathrm{cm}^{2}$ とし、磁場の强さ壮 274 ガウスととた。：

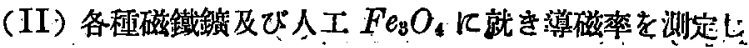

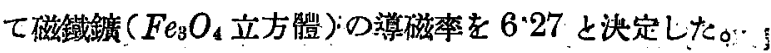

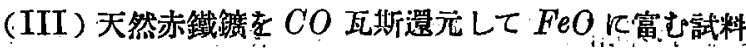

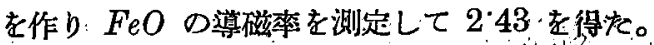

(IV) 天然磁鐵鏣及び還元して得たる、各画酸化鐵の導磁， 率の關係を求むれ独第2圖の樣儿なる。

(V) 天然磁鐵艔及び還元試料の真空加熱溫度と導磁率 の關係は第 5 圖の如くなり、.650〜 $700^{\circ} \mathrm{C}$ 真空扠熱にて急

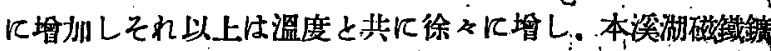
は $700^{\circ} \mathrm{C}$ 以上一定になる，而して還元陚料は天然磁鐵鋂 より加熱に上る導磁率の增加大である。

(VI) 天然磁鐵鑛及び還元して得だる酸化物 $650^{\circ} \mathrm{C}$ 以上眞空州熱すれば尊磁率を增加する。

(VII) $\mathrm{Fe}_{3} \mathrm{O}_{4}$ は 59 〜00 C Kて磁氣變態を示する。.

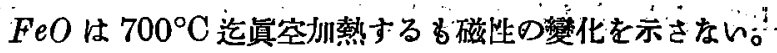

(VIII) $H_{2}$ 瓦斯還元試料を $650^{\circ} \mathrm{C}, 80^{\circ} \mathrm{C} ; 1 ; 000^{\circ} \mathrm{C}$

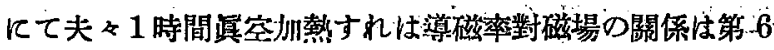
圖の如くなり溫度の上昇に從ひ濑次天然磁鐵鈸に接近し.て 居る。

(IX) $\mathrm{FeO}$ 及び $\mathrm{Fe}_{2} \mathrm{O}_{3}$ が完全氏 $\mathrm{Fe}_{3} \mathrm{O}_{4}$ を形成し殘剩

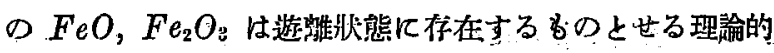

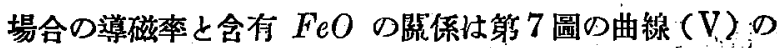
如く $31 \% \mathrm{FeO}$ にて最大導磁率を示しそれを境にして坦娍 认て居る。

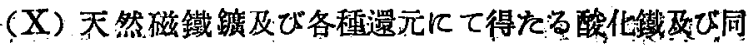

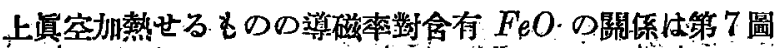
曲線 I. II. IV，の如くにて還元にて得える酸化鐵恃 $38 \%$ にて最大導磁率を示し理諭的場合と趣を異にして居るが真 空加熱すれば漸次理論的場合に接近する事を示してるる。

(XI) 天然磁鐵鏣及び $H_{2}$ 及び $G O$ 真斯還元にて得た る酸化鐵の酸素結合狀態を $\mathrm{FeO}$ 及び $\mathrm{Fe}_{3} \mathrm{O}_{4}$ の導磁本老: 基礎とし、前述諸關係を参照して推理すれ仗第 9 表の如く なる。即ち $\mathrm{FeO}$ 及び $\mathrm{Fe}_{2} \mathrm{O}_{3}$ は一部分 $\mathrm{Fe}_{3} \mathrm{O}_{4}$ 立为體飞て

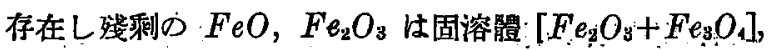
$\left[\mathrm{Fe}_{3} \mathrm{O}_{4}+\mathrm{Fe}_{2} \mathrm{O}_{3}\right],\left[\mathrm{Fe}_{3} \mathrm{O}_{4}+\mathrm{FeO}\right],\left[\mathrm{FeO}+\mathrm{Fe}_{3} \mathrm{O}_{4}\right] ;[\mathrm{FeO}$ $+\mathrm{Fe}]$ 及び遊離 $\mathrm{FeO}$ として存在して居る。直空州熱すれ ばてれら固溶體が解離作用を起して $F e_{3} O_{4}$ 立方體をない. 磁性を增加する。

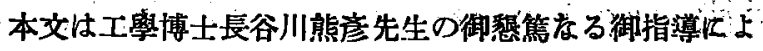
りたるものにして、こてに厚く感謝する次第である。 